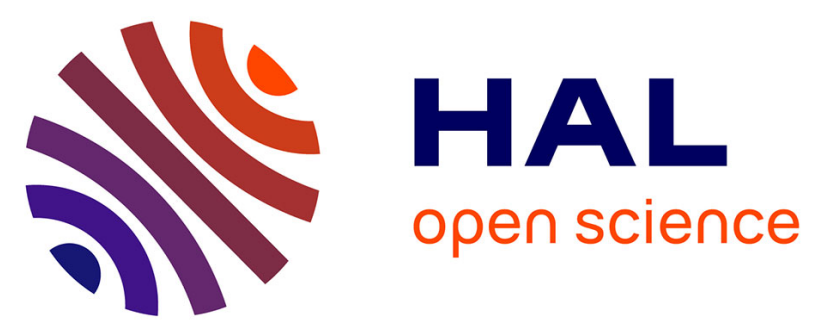

\title{
Early occupation of High Asia: New insights from the ornaments of the Oshhona site in the Pamir mountains
}

Alexander Yu. Fedorchenko, William T.T. Taylor, Nuriddin Sayfulloev, Samantha Brown, William Rendu, Andrei Krivoshapkin, Katerina Douka, Svetlana Shnaider

\section{To cite this version:}

Alexander Yu. Fedorchenko, William T.T. Taylor, Nuriddin Sayfulloev, Samantha Brown, William Rendu, et al.. Early occupation of High Asia: New insights from the ornaments of the Oshhona site in the Pamir mountains. Quaternary International, 2020, 559, pp.174-187.

10.1016/j.quaint.2020.07.026 . hal-03043553

\section{HAL Id: hal-03043553 \\ https://hal.science/hal-03043553}

Submitted on 13 Dec 2020

HAL is a multi-disciplinary open access archive for the deposit and dissemination of scientific research documents, whether they are published or not. The documents may come from teaching and research institutions in France or abroad, or from public or private research centers.
L'archive ouverte pluridisciplinaire HAL, est destinée au dépôt et à la diffusion de documents scientifiques de niveau recherche, publiés ou non, émanant des établissements d'enseignement et de recherche français ou étrangers, des laboratoires publics ou privés. 


\title{
Early occupation of High Asia: New insights from the ornaments of the Oshhona site in the Pamir mountains
}

\author{
Alexander Yu. Fedorchenko a, ${ }^{,}$, William T.T. Taylor b, Nuriddin N. Sayfulloev c, Samantha Brown d, William \\ Rendu e, Andrei I. Krivoshapkin a,g, Katerina Douka d,f, Svetlana V. Shnaider a,g
}

a Institute of Archaeology and Ethnography, SB RAS, Novosibirsk, Russia

b Museum of Natural History/Department of Anthropology, University of Colorado-Boulder, Boulder, CO, USA

c Institute of History, Archaeology and Ethnography, Dushanbe, Tajikistan

d Max Planck Institute for the Science of Human History, Jena, Germany

e CNRS, PACEA-UMR 5199, Universit'e de Bordeaux, Minist'ere de La Culture et de La Communication (MCC), F-33400, Pessac, France

f Oxford Radiocarbon Accelerator Unit, University of Oxford, Oxford, UK

g Novosibirsk State University, Novosibirsk, Russia

\begin{abstract}
A B STRACT
The Pamir plateau is one of the highest mountain systems in the world, presenting a highly challenging environment for human occupation. During the Soviet era, researchers discovered several stratified archaeological sites in the Pamir zone - including the Oshhona site, which yielded a large collection of lithic artefacts and personal ornaments made of bone. Pairing archaeozoological and biomolecular methods (Zooarchaeology by Mass Spectrometry) with use-wear analysis, we investigate the tradition of personal bone ornament production that emerged in the Pamir mountains during the Middle Holocene. Our analyses indicate that inhabitants of Oshhona site used a wide range of faunal remains to manufacture non-utilitarian items - including pendants, elongated beads, and engraved bone. Comparison of raw materials, manufacture technology, and style provide compelling evidence of cultural links between the Pamir and the middle highlands of the Tian Shan. Although available anthropological and genetic evidence is too scattered to assess the possibility of population movements, our results point to a shared techno-cultural tradition or common cultural adaptation in bone ornament production across these two regions, perhaps developing as a response to life at high altitudes in Central Asia during the Middle Holocene.
\end{abstract}

Keywords: Central Asia Epipalaeolithic Personal ornaments ZooMS AMS dating Use-wear analysis Technological analysis

\section{Introduction}

Although Central Asia is renowned for its particularly rich cultural heritage, and its essential role in the movements of people, technology, goods, and ideas, from the Pleistocene to the modern era (Harris et al., 1993; Chaix et al., 2007; Kuzmina, 2008; Dennell, 2009; Brunet, 2012; Rybin, 2014; Sharon, 2014; Pinhasi and Heyer, 2015; Kolobova et al., 2016; Bae et al., 2017; Narasimhan et al., 2019; Zwyns et al., 2019), much of this area poses unique challenges to human occupation. The initial human settlement of the Central Asian territory - which ranges from the Eastern Caspian and Kopet Dag Mountains in the West to Tibet, Dzungaria and the Altai in the East - during the Late Pleistocene and Early Holocene required adaptation to high-altitude areas (2500-4500 m asl). Severe climatic and environmental challenges at high altitudes (including cold, hard winters, and limited oxygen) forced human populations to develop biological, economic and technologic adaptations (Brantingham et al., 2007; Meyer et al., 2017; Slon et al., 2018; Zhang et al., 2018; Taylor et al., 2018; Taylor et al., 2019; Shnaider et al., 2020). However, we know a little about the symbolic activities of early human societies in these environments. Personal ornaments, made of various organic and mineral raw materials, represent an essential element of cultural assemblages among the first occupants of highland Central and Inner Asia (Fig. 1). The first symbolic behaviour found across this broad region comes from Initial 50.0-30.0 ka cal BP (Rybin, 2014; Douka et al., 2019). Finds of ornaments from the Altai Mountains (Derevianko and Rybin, 2003; Derevianko and Shunkov, 2004; Shunkov et al., 2018; Fedorchenko et al., 2020), Transbaikalia (Lbova, 2000; Tashak, 2002), Mongolia (Derevianko et al., 2007; Zwyns et al., 2014; Khatsenovich et al., 2017) and the Ordos (Martí et al., 2017; Wei et al., 2016, 2017) show that ornament production was an important part of early human cultures across Inner Eurasia, which come from contexts ranging from 5 to $1500 \mathrm{~m}$ asl. The mass production of personal adornments was either an original cultural innovation or a response by local peoples to the arrival of a new population. Various types of ornaments worn in certain combinations may have been crucial markers of gender or age, tribal or clan affiliation, marital status, social standings, or levels of wealth (d'Errico et al., 2003; Kuhn and Stiner, 2007). While a general picture of cultural and technological changes occurring during the Initial and Early Upper Paleolithic of Central Asia has been established based on flaked stone tools (Kolobova et al., 2016), no reliable evidence for the presence of personal ornament production is known for this area - particularly for the earliest sites found at higher elevations of $2500 \mathrm{~m}$ asl and above. In the Early and Middle Holocene, various types of non-utilitarian objects made of bone, stone, and mollusc shells proliferated across lowland areas of Central Asia from the Aral- 
Caspian depression to the Ferghana Valley (Okladnikov, 1956; Gulyamov et al., 1966; Markov, 1966; Vinogradov, 1981; Islamov and Timofeev, 1986; Shnaider et al., 2018; Fedorchenko et al., 2018a). Ornaments made of organic or stone raw material from mountain areas in Central Asia are known only from the northern Tian Shan and Hissar ranges, and date to the terminal Late Pleistocene - Early Holocene (Fedorchenko et al., 2018b; Ozherelyev et al., 2019; Nokhrina and Taimagambetov, 1996; Islamov, 1975). In the Soviet era, many ornaments and symbolic artefacts from mountains areas of Central Asia were identified from archaeological sites without radiocarbon dates or surface assemblages with problematic stratigraphy (Vinogradov, 1955, 1981; Gulyamov et al., 1966; Vinogradov and Mamedov, 1975; Islamov, 1980; Bizhanov, 1982; Itina, 1984; Islamov and Timofeev, 1986; Korobkova, 1989). The chronological and cultural attribution (Epipalaeolithic, Mesolithic or Early Neolithic) of personal adornments from this territory was usually determined using via relative dating based on accompanying stone tools or ceramics. Many Soviet publications reported only the presence or absence of ornaments and raw material type. As a result, traditions of manufacture, selection of raw materials, and use of these items - along with their complex social, cultural, and aesthetic functions, - have gone unnoticed or unstudied. Overall, early evidence of personal ornament production is still rare in Central Asia. Here we present a detailed analysis of the collection of bone ornaments from the site of Oshhona in the Pamir Mountains, Tajikistan, one of the oldest archaeological sites situated in the high mountains of Central Asia (Ranov, 1962; Shnaider and Saifuloev, 2018). The Oshhona personal adornments were recovered from secure archaeological contexts; a series of wellcorrelated radiocarbon dates have been generated for the site's cultural layers (Ranov and Karimova, 2005). The combination of absolute chronology and contextual information relating to the recovered ornaments, paired with the detailed study of material and manufacture technique, allows us to discuss the technology and production of symbolic objects by early human populations occupying the high mountain zones of Central Asia.

\section{Regional settings}

Situated in the heart of Central Asia, the Pamir mountains are located at the intersection between the Karakorum, Hindukush, Kunlun and Tian Shan mountains. The climate is arid, with short summers and long winters (minimum temperatures reaching $-47 \cdot \mathrm{C}$ ). The mountainous landscape is split by broad rivers and lake valleys, with elevations ranging from 3600 to $4200 \mathrm{~m}$ asl. Pamir vegetation is characterized by cryophytic alpine and subalpine meadows. Local populations in the Eastern Pamir consist mostly of ethnic Kyrgyz herders, who practice a traditional nomadic lifestyle and undertake (with their livestock, sheep, goat, and yak) several altitudinal migrations during the year. Wild fauna important to humans includes the Marco Polo sheep (Ovis ammon polii), Siberian ibex (Capra sibirica), Snow leopard (Uncia uncia), Eurasian lynx (Felix lynx), wolf (Canis lupus), and long-tailed marmot (Marmota caudata) (Saidov, 2008). Systematic archaeological research in the Pamir mountains was conducted during the Soviet era (1950-1970) by research teams led by V.A. Ranov and V.A. Zhukov (Ranov, 1962; Zhukov, 1982; Ranov and Khudzhageldiev, 2005). In the eastern Pamir, these projects identified dozens of archaeological sites, most of which consisted of surface scatters. However, Ranov and Zhukov also identified two well-stratified localities, known as Oshhona and Istikskaya Cave (Zhukov, 1982; Ranov, 1988). Oshhona - analysed here - is an open-air site located in the northern Pamir, within the Markansu valley. Vadim Ranov and his team discovered this site in 1957 and excavated an area of 563 m2 between 1957 and 1960. Archaeological remains were found at a depth of 0.2-1.5 m below the surface. Ranov identified four cultural layers, which he considered to belong to a single cultural complex. In the lithic assemblage, Ranov identified two knapping strategies. The first was based on pebble knapping, which was used to produce large flakes as blanks for scrapers. The second knapping strategy involved production the microblade by pressure knapping, wherein microblades were retouched and used as composite tools. The toolkit also contained endscrapers, awls, bifacial small arrows, notched bladelets, and backed bladelets. Previous researchers obtained a set of radiocarbon dates ranging between 11,202 and 10,512 cal BP for layer 2, and 8163-7690 cal BP and 8509-7880 cal BP for layer 3 (2-sigma or $95.4 \%$ probability, calibrated using IntCal13 in OxCal version 4.3). Researchers remain sceptical about the quality of dates from the second cultural layer, however, and tend to use only the later range of dates when describing the site (Ranov and Karimova, 2005). Since the original excavation, the personal ornaments from the site remained unstudied.

\section{Materials and methods}

Here we analyse the original collection of bone artefacts from layer 1 of the Oshhona site (Fig. 2). A total of six bone items occurs from this stratigraphic unit. These include a pendant with a perforation made of the wall of a tubular bone; a pendant with a hole made from a mammalian tooth; two elongated beads made of tubular small mammal bone; an elongated bead made of tubular bone of a carnivore; and a fragmented engraved bone.

\subsection{Zooarchaeological study}

Based on skeletal morphology, we identified each specimen to the most precise taxonomic level using comparative collections at the Russian Academy of Sciences-Siberian Branch in Novosibirsk, Russia. In cases where we could not make a species attribution, we used size classes (Brain, 1981). Identifiable specimens (including shaft fragments) were analysed for skeletal element, portion, and segment (Gifford and Crader, 1977). Next, we conducted a microscopic observation of all bone to identify taphonomic modifications, including weathering, root etching, anthropogenic, and carnivore damage (Olsen and Shipman, 1988; Blumenschine et al., 1996; Behrensmeyer, 1978; d'Errico and Villa, 1997; Pickering and Egeland, 2006).

\subsection{Zooarchaeology by Mass Spectrometry (ZooMS)}

As most specimens could not be easily identified to taxon based on morphology, we conducted Zooarchaeology by Mass Spectrometry (ZooMS) analysis to taxonomically identify the bone artefacts at the Max Planck Institute for the Science of Human History in Jena, Germany. We followed protocols outlined by Welker et al. (2015), allowing samples to demineralise in $0.5 \mathrm{M}$ hydrochloric acid for one-two days after which they were rinsed back to a neutral $\mathrm{pH}$ using $50 \mathrm{mM}$ ammonium bicarbonate. After rinsing, the sample was incubated at $70 . \mathrm{C}$ for an hour in $100 \mu \mathrm{l}$ of $50 \mathrm{mM}$ AmBic. $50 \mu \mathrm{l}$ of the resulting supernatant was treated with trypsin (Pierce TM Trypsin Protease, 
Thermo Scientific) at $37 \cdot \mathrm{C}$ for $18 \mathrm{~h}$. Following digestion, we subjected samples to $\mathrm{C} 18$ cleanup (Pierce ${ }^{\mathrm{TM}} \mathrm{C} 18 \mathrm{Tips}$, Thermo Scientific), mixed with a matrix solution of $\alpha$-cyano-4-hydroxycinnamic of $10 \mathrm{mg} / \mathrm{mL}$ in $50 \%$ acetonitrile (ACN)/0.1\% trifluoroacetic acid (TFA) and allowed them to co-crystallise. Samples were then analysed using an Autoflex MALDI-TOF Bruker Ultraflex II (Bruker Daltonics, Bremen) Matrix Assisted Laser Desorption lonization (MALDI) Time of Flight (ToF) Mass Spectrometer. The resulting mass spectra were analysed using mMass and screened for diagnostic markers using the FlexAnalysis software and compared against a reference library (Buckley et al., 2009; Welker et al., 2016). Samples were also analysed alongside multiple blanks which all returned negative results, hence no crosscontamination was observed.

\subsection{Technological and use-wear analysis}

Using the technological approach and use-wear analysis, we reconstructed the technological context, sequence, and methods of production of artefacts (Averbouh, 2001; d'Errico et al., 2003; Broglio et al., 2004; White, 2007; Khlopachev and Girya, 2010; Goutas, 2015; White and Normand, 2015), following procedures developed by previous research (Vanhaeren and d'Errico, 2006; White, 2007; Wright et al., 2014; Heckel, 2016) and adapted to our region (Shunkov et al., 2018; Fedorchenko et al., 2018a). First, we measured each artefact using electronic sliding callipers with a margin of error of $0.1 \mathrm{~mm}$. We then conducted a use-wear analysis of the bone items to identify traces accumulated during manufacture and use at both low and high optical magnification, following established protocols (Semenov, 1968; Campana, 1979; Peltier and Plisson, 1986; Buc and Loponte, 2007; Legrand and Sid'era, 2007; Kononenko, 2011; Wright et al., 2014; 'Evora, 2015; Bradfield, 2015; Marreiros et al., 2015; Stemp et al., 2015; Dayet et al., 2017; Martisius et al., 2018). Special attention was paid to the detection of the organic and inorganic remains on the artefact surfaces (Wadley et al., 2004; Rigaud et al., 2014; Martí et al., 2017; Velliky et al., 2018). We conducted a preliminary observation of every bone artefact using a stereomicroscope Altami SM0745-T with an external light source and with magnifications ranging from $7.5 \times$ to $100 \times$. The main instrument used in a detailed examination of use-wear and manufacture traces - such as scarring, rounding, striations, and abrasion polish - was a metallographic microscope Olympus BHM, using differential interference contrast (DIC) lenses with $40 \times$ to $500 \times$ magnifications. We recorded each artefact using a Canon EOS 7D digital SLR camera with lenses EF-S $60 \mathrm{~mm} \mathrm{f/2.8} \mathrm{Macro} \mathrm{USM} \mathrm{and} \mathrm{a} \mathrm{tripod} \mathrm{with} \mathrm{manual} \mathrm{focusing.} \mathrm{Micro-photography} \mathrm{utilized} \mathrm{a} \mathrm{Canon}$ EOS 7D and Olympus BHM optical system. For the creation of microphotographs focusing over the entire frame, we used Helicon Focus software, which is based on focus stacking technology.

\subsection{Experimental data}

Experimental criteria to identify bone artefact production techniques from the Final Pleistocene and Early Holocene have been productively applied to archaeological assemblages (Semenov, 1968; Olsen, 1984; Campana, 1989; LeMoine, 1994; Gwinnett and Gorelick, 1998; Korobkova and Sharovskaya, 2001; Maigrot, 2003; Pickering and Egeland, 2006; Legrand and Sid'era, 2007; Khlopachev and Girya, 2010; Buc, 2011; Averbouh and Pétillon, 2011; 'Alvarez et al., 2014; Abuhelaleh et al., 2015; Gurova and Bonsall, 2017; Torres et al., 2020). To understand the Oshhona material, we also used our experimental collection, produced to examine the manufacture and use-wear traces on artefacts made of mineral and osseous raw material. We employed various techniques and technologies for osseous raw material processing known from prehistoric Eurasia (Fedorchenko, 2013, 2016; Fedorchenko et al., 2017, 2018a). Our experimental program included modification of long bones of Rangifer tarandus, Cervus elaphus, Bos taurus taurus, and Ovis aries in dry and soaked condition. These experiments explored techniques for making longitudinal grooves in bone with stone burins, knapping and intentional fragmentation of bone raw material with hammerstones, wedges, and anvils, as well as planing/scraping of bone blanks using stone flakes, blades, and burins. We made an experimental grinding using grindstones made from sandstone and other abrasive raw material. We conducted perforation experiments using hand drilling, non-modified flint flakes with a narrow triangular shape, and a wooden bow drill with retouched micro-borer. We also relied on the reference collection at the Experimental-Traceological Laboratory of the Institute for the History of Material Culture RAS, Saint Petersburg. The conclusions of our experimental studies were used in the identification of the manufacturing techniques of the Oshhona bone artefacts.

\section{Results}

\subsection{General characteristic of the faunal assemblage}

The faunal assemblage of the site from V.A. Ranov excavation consists of 130 specimens (Table 1). The material is highly fragmented, and no complete elements were found. Based on the taphonomic study, most of this fragmentation occurred in antiquity while the bones still contained the grease and marrow. Less than $10 \%$ of the observed fractures were made on dry bones. Other taphonomic modifications are rare in the Oshhona assemblage, and limited weathering is present on only $30 \%$ of the remains. We do not observe carnivore marks and see root etching only on less than $10 \%$ of the remains. Of the 130 bone fragments, only 12 were taxonomically identifiable. These are all specimens of sheep or goat (Ovis/Capra), and include fragments of long bones (Femur $=2$; Tibia $=2)$, metapodial $(n=4)$, scapula $(n=1)$, second phalange $(n=1)$ and tooth fragments $(n=2)$. In addition, 41 other remains were attributed to small- and medium-size ungulates (long bones $=17$; flat bones $=13$; vertebrae $=1$ ). All these small/medium size ungulate remains could also belong to Ovis or Capra. In total, 19 specimens (14.6\%) exhibit evidence of human activity. We identified cutmarks on five elements, including two femur shafts (likely related to defleshing) and two metapodials (disarticulation marks). Notches and bone percussion flakes attest to bone breakage, probably in order to recover marrow and grease.

4.2. Species identification of the blanks for personal ornaments Although the process of ornament production removed most identifiable features of the bones necessary for species identification using traditional zooarchaeological techniques, three of the six specimens revealed high confidence taxonomic identifications based on collagen peptides using ZooMS. Two addition samples (samples 4 and 5) retain taxonomically essential markers but lack enough diagnostic markers to give high confidence assignments. Our results (Table 2) indicate the use of medium/large mammal species which may be wild or domestic (Ovis and Capra), small mammal prey species (rabbit/hare and Muridae, which may belong to a field mouse), and a predator species (cat), showing diverse exploitation of the mammalian fauna of the Pamir region. 
4.3. Production process The pendant made of Capra/Rangifer tubular bone is diamond-shaped (Table 2: sample 3; Fig. 3), with a straight profile and convex-concave cross-section following the original shape of the blank. The item is $22.1 \mathrm{~mm}$ long, $10.3 \mathrm{~mm}$ wide and from 1.3 to $2.5 \mathrm{~mm}$ thick (maximum dimensions). The pendant is made from a bone blank produced through fragmentation of a long bone through percussion. A few large chipping facets are noted at the bottom of the concave side of the artefact. Such traces are characteristic of the technique of direct percussion with a hammerstone (Pickering and Egeland, 2006). We note a traces of premeditated planing close to the perforation in the upper portion of the item's convex side. Evidence for planing is, however, difficult to distinguish due to overlapping usewear traces and, sometimes, root etching. The perforation has a round shape and biconical profile and is located in the upper portion of the artefact. The diameter of the hole is $3.5 \mathrm{~mm}$. The interior surface of the hole shows concentric drilling striations arranged in even, parallel rows (Fig. 4). Upon marking the point intended for drilling on the concave side of the bone, a cone-shaped hole appears to have been formed by a stone tool with a narrow symmetrical point. The resulting perforation was drilled from the opposite side with the same tool. Morphological parameters of the perforation suggest the use of two-way drilling (Olsen, 1984: 153; Torres et al., 2020). The shape of the hole suggests that drill rotated smoothly and freely around its axis, which could indicate the use of a bow drill (Gwinnett and Gorelick, 1998). Use-wear analysis of the pendant revealed use of this object in everyday life and wear. Under $40 \times-100 \times$ magnification, the convex side of the pendant close to the perforation shows micropolish, shallow multi-directional scratches and micro indentations, located mainly at protruding areas of the surface. On the concave side of the ornament, there are traces of rubbing and general use-wear resulting from contact with soft organic material (LeMoine, 1994). The pendant's edges are rounded at the micro-level and show traces of lustre. At the top of the perforation, a localized area of smoothing and rubbing along with signs of overlapping concentric drilling striations is visible. These use-wear traces indicate a relatively firm attachment of the object to clothing with a thin thread (Dayet et al., 2017). The pendant made from an Ovis/Cervidae/Saiga tooth (Table 2: sample 2; Fig. 5), is elongated and ovoid, with a straight profile and a subrectangular cross-section, which is due to the natural shape of the blank. The surfaces of the two lateral edges and one of the wide sides of the adornment are almost entirely missing due to lengthwise fragmentation. The object is $19.5 \mathrm{~mm}$ long, $7.3 \mathrm{~mm}$ wide and $2.8 \mathrm{~mm}$ thick (maximum dimensions). A round hole, biconical in the cross-section, was made in the root portion of the tooth. The diameter of the hole is $2.2 \mathrm{~mm}$. Manufacture and use-wear traces on the artefact are partially destroyed due to exfoliation and desiccation-related fracturing. Traces of drilling preparation by planing or scraping, typical for pendants made of animal teeth (White and Normand, 2015: 145), are not visible on this artefact.

Morphological features of the perforation indicate the use of a two-way drilling technique using a small tool (Gwinnett and Gorelick, 1998). Micropolish on the upper part of the pendant and rub marks inside the hole, which overlap the concentric drilling striations, may suggest a relatively long and free movement of the pendant along the thread. Similar traces are considered as evidence of contact with the clothing or skin of a person who wore this ornament in everyday life (LeMoine, 1994). The elongated bead made of tubular bone from a small rabbit or leporid (Table 2: sample 4; Fig. 6) has a narrow cylindrical shape, straight profile, and ovoid cross-section. These features follow the morphology of the original blank. The bead is $10.6 \mathrm{~mm}$ long, $3.3 \mathrm{~mm}$ wide and $2.7 \mathrm{~mm}$ thick (maximum dimensions). The diameter of the natural hole is $2 \mathrm{~mm}$. At the initial stage of the elongated bead production, the epiphysis of the tubular bone was cut through deep, circular sawing and subsequently broken via flexion (Buc, 2011: 551) (Fig. 7: 1). The cutting surface is inclined at an angle of 80 . to the cross axis of the item. The bead ends show four tentative cutmarks. The first is $2.9 \mathrm{~mm}$ long on one of the wide sides, and three other marks are $2.7 \mathrm{~mm}, 1.7 \mathrm{~mm}$ and $0.8 \mathrm{~mm}$ long on the opposite side. Analysis of manufacture traces suggests that the cutmarks were produced by a stone tool with reciprocal kinematics, straight profile, and symmetrical V-shaped working edge (Wright et al., 2014). At the next stage, the item was carefully processed with fine-grained abrasives. Under $40 \times-200 \times$ magnification, the grinding traces appear as rows of elongated thin scratches oriented sub-parallel and perpendicular to the longitudinal axis of the artefact (Bradfield, 2015) (Fig. 8). Traces of grinding are overlapped and obscured by utilization wear across the surface of the decoration. Under $40 \times-100 \times$ magnification, the bead surfaces display visible traces of use-wear; micropolish is noted all over the rough microrelief; with rubbing signs and shallow micro indentations also visible (Fig. 7: 2). The surfaces of scratches and breakages at the bead ends are also smoothed and polished through prolonged use. This use-wear pattern suggests that the item was used together with other typologically similar artefacts as a part of a necklace. The elongated bead made of tubular bone from a cat (Felidae) (Table 2: sample 6; Fig. 9) is barrel-shaped and has a rounded cross-section and a straight profile. The decoration is $12.3 \mathrm{~mm}$ long. The width of the items varies from $5.5 \mathrm{~mm}$ in the medial part to 4.2 $\mathrm{mm}$ at the ends. The thickness of the bead varies similarly: from $3.4 \mathrm{~mm}$ to $4.3 \mathrm{~mm}$ at the ends to $5.3 \mathrm{~mm}$ in the medial portion. The diameter of the natural hole is $2.5 \mathrm{~mm}$ on one side and $3.3 \mathrm{~mm}$ on the opposite side. The initial stage of bead production was similar to that described above: the tubular bone epiphysis was cut or sawn with deep notches around the circumference of the bone, which was subsequently broken in the artisan's hands. The cutting surface was inclined at an angle of 50-60。 to the long axis of the object. Tentative cutmarks, $3.9 \mathrm{~mm}$ and $3.4 \mathrm{~mm}$ long, were noted on opposite sides at one of the bead's ends. The morphometric features of these traces suggest the use of a stone tool with a small symmetrical V-shaped working edge, such as an unretouched bladelet or flake. The exterior bead surfaces display visible use-wear traces: micropolish, rubbing traces, and shallow micro dents (Olsen, 1984: 168). The elongated bead, the same as the bead described above, might have been used as part of a necklace. The elongated bead made of a tubular bone from Muridae (Table 2: sample 5; Fig. 10) is cylinder-shaped, slightly expanding in diameter from one end to the other, with a straight profile and a flat-convex cross-sectional shape. The length of the artefact is $10.2 \mathrm{~mm}$, the width is $6.3 \mathrm{~mm}$, and the thickness is $5.2 \mathrm{~mm}$ (maximum dimensions). The diameter of the hole is $2.5 \mathrm{~mm}$ at one of the ends and $3.2 \mathrm{~mm}$ at the opposite end. Manufacture and usewear traces are poorly preserved due to natural deformation by exfoliation and pitting of the surface. The greater part of one of the broad bead surfaces has traces of exfoliating. The opposite surface and lateral faces of the item are less deformed. The general state of artefact preservation suggests the use of the same technological sequence as for the previous two ornaments. One of the bead tops was formed by circular sawing of the bone surface; the surfaces of the cutmarks are smoothed by planing and show use-wear micropolish. Sawing marks are not visible on the opposite end of the artefact; here the surface is levelled and ground; inside one micro-indentation, tiny particles of red ochre pigment are traced. We do not note the evidence of additional treatment inside the resulting natural hole. The foliate sheep (Ovis) bone fragment with traces of engraving (Table 2: sample 1; Fig. 11) shows a slightly curved profile and a flattened cross-section. Traces of fragmentation are discernible over much of the item's perimeter. The artefact is $55.6 \mathrm{~mm}$ long, $16.3 \mathrm{~mm}$ wide and from 1.1 to $2 \mathrm{~mm}$ thick (maximum dimensions). Five elongated engraved lines are made by a stone tool with a thin $U$-shaped working edge (Fig. 12). Sub-parallel traces of linear decoration are arranged diagonally to the artefact long axis. The lengths of the lines vary from 13.1 to 
$37.5 \mathrm{~mm}$, the widths range from 0.1 to $0.2 \mathrm{~mm}$, and the depth is $0.1 \mathrm{~mm}$. Under $40 \times-100 \times$ magnification all grooves are relatively consistent in size and shape, which may suggest a smooth hand movement, and uniform tool specialised stone instrument like a small burin or engraver could have been used to create the ornament. We do not fix any other shreds of evidence of intentional manufacture on the artefact surfaces.

4.4. Age determination We conducted new absolute dating of the Oshhona site assemblage using samples obtained from two bone fragments found in the archaeological collections stored at the Archaeological Department of the Institute of History, Archaeology and Ethnography (Dushanbe, Tajikistan). The samples were processed and dated at the AMS laboratory of the Centre for Cenozoic Geochronology, Institute of Archaeology and Ethnography SB RAS (Novosibirsk, Russia) and in the Centre for Isotope Research of Groningen University (Groningen, Netherlands) (Table 3). A sample from layer 1 gave a 14C Age of 6817 \pm 104 BP (NSKA-1634) and calendar Age of 7922-7493 BP (2-sigma calibrated range using the INTCAL 13 calibration curve in OXCAL 4.3). The next sample obtained from layer 2 yielded an age of $6232 \pm 105$ BP (NSKA-1632) and 7415-6889 cal BP (2-sigma calibrated range). Finally, a third sample from the same layer, processed at the Centre for Isotope Research at the University of Groningen, gave a $14 \mathrm{C} \mathrm{Age} \mathrm{of} 6824 \pm 18$ BP (GrM- 11930 ) and a calibrated age of 7685-7615 cal BP (2-sigma). Considering these new dates alongside the results of previous studies (Fig. 13), both layer 1 (where all the ornaments were found) and layer 2 appear to date to ca. $7650 \mathrm{BP}$, with the possibility of later occupation as well (that could also be attributable to radiocarbon contamination from specimen NSKA-1632). We suppose, the date $9530 \pm 130 \mathrm{BP}$ (RUL-280) is incorrect for layer 2; this sample was obtained from charcoal that may not directly reflect the age of cultural activity. Layers 3-4 may slightly predate the overlying layers, with previous dates falling between 8.5 and $7.7 \mathrm{ka}$ cal BP.

\section{Discussion}

We discovered that inhabitants of the Oshhona site used osseous raw material from several local animal species to produce personal ornaments of various types. Archaeozoological and biomolecular analysis show that bone raw material belonging to a wide range of wild animal taxa - deer, sheep, goat, cats, and rabbits/hares. The manufacture of the bone ornaments from Oshhona also employed several operational sequences. The technology of pendant production from mammalian teeth or wall of tubular bones was relatively simple using a short sequence: extraction of the tooth or selection of bones of suitable size/shape, preparation of the surface through planing or scraping, and finally two-way perforation of a rounded hole, likely using a simple device such as a bow drill. The manufacturing of elongated beads implied a more extended operation sequence. It included the following stages: removing the epiphysis of the tubular bone through deep circular cutting or sawing, breaking of the bone via flexion, and processing the surfaces with fine-grained abrasives. Use-wear patterns identified on these artefacts suggest that ornaments from Oshhona were used as the elements of a necklace, or sewn onto clothing. Comparison of our results with the archaeological record of the broader region of Central Asia suggests that occupants of mountain zones seem to have exploited local fauna while lowland occupants preferred other raw materials (Table 4). In the middle highlands of Central Asia, the earliest evidence of personal ornaments occurs from the multilayered site of Aigyrzhal-2, located in the Tian Shan mountains at an elevation of $2000 \mathrm{~m}$ asl (Motuzaite Matuzeviciute et al., 2017; Fedorchenko et al., 2018b). At this site, a pendant with circular cutmarks made of a Cervus incisor was found in association with cultural layer 3 dated to 13.4-13.0 ka cal BP. A few pendants of Corbicula tibetensis shells with holes and red ochre have been reported at Rakhat multilayered site in the piedmonts of the Trans-Ili Alatau, one of the northern ranges of the Tian Shan (Ozherelyev et al., 2019). This assemblage is preliminarily dated to the terminal Upper Palaeolithic. A unique set of personal ornaments also occur in association with the Early and Middle Holocene layers of the Karaungur Cave on the southern face of the Karatau mountain range (northwestern Tian Shan) (Nokhrina and Taimagambetov, 1996). The collection of bone items includes pendants made from teeth of small predators (Meles meles and Vulpes vulpes) and red deer (Cervus elaphus). This assemblage contains quadrilateral and round-shaped pendants with decorative motifs and red ochre, made of long bone fragments, as well as cylinder-shaped elongated beads decorated with linear incisions. Personal ornaments made from non-osseous raw material also revealed in Karaungur. These include an ovoid and patterned pendant made from slate, two cone-shaped elongated beads made of Corbicula ferganensis shell, and a pendant made of Dentallium sp. shell coloured with red ochre. A single ring-shaped bone pendant is known at Late Mesolithic assemblage of Machai Cave which is located in Baisuntau range and dated to 8.6-8.15 ka cal BP (Islamov, 1975). More significant numbers of personal ornaments have been found in the assemblages of the low-mountain area of Central Asia, typically using stone rather than bone as raw materials for manufacture. The oldest evidence of symbolic activity for this territory occurs in the Fergana valley in the Early Holocene layers of Obishir-5 site (altitude $1700 \mathrm{~m}$ asl), dated to 10.8-8.2 ka cal BP (Shnaider et al., 2017; Fedorchenko et al., 2018a). The assemblage is made of soft stone and bone. The Obishir personal adornments include five artefacts made of talkite, serpentinite, and marble, produced through grinding and drilling. These are ovoid, subtriangular, and subrectangular pendants, a labret-like item, and a pendant blank. For the manufacture of stone ornaments, inhabitants of the Obishir-5 used raw material transported to the site over a distance of $4.5 \mathrm{~km}$. The Early Holocene complex from this site also includes a pendant made of a Canis deciduous tooth with one biconical perforation (Islamov, 1980: 73). Other evidence of personal ornament production in the Fergana valley discovered through archaeological research is dated to the Mesolithic and Early Neolithic. This includes the sites of Uzunkul-1, -2 and -5 ; Dorazkul-1; Yangikadam-12, -16, -19, -25-27, -31, -32 and -35; Taipak-1, -9-12; Gurtepe; Madiar-1-3, -10a, and -13 sites (Islamov and Timofeev, 1986). For the manufacture of most non-utilitarian items from these sites, ancient inhabitants of Fergana valley used various types of soft stone. There are plain, rounded pendants made of small pebbles of marble-like rocks. These adornments have biconical perforations and are decorated through small carved notches at the edges. Small round beads are less common. A fragment of a complexshaped polished artefact, possibly a ring or a bracelet made of greenish-brown soft stone represents a unique find at the Madiar-2 site [Ibid: 100]. This artefact is curved and has a flattened cross-section. We should caution that the arid climate, typical of most of the landscape zones of Central Asia, may not be favourable to the preservation of animal bone ornaments in lower-lying areas. Nonetheless, osseous raw materials were undoubtedly known to the Epipalaeolithic and Early Neolithic inhabitants of Fergana, and consideration of these archaeological sites show that bone was widely used for the manufacture of non-utilitarian items. Finally, across the Aral-Caspian depression and Amu-Darya-Syr- Darya interfluve, personal ornaments appear to have been produced largely using shell and ornamental stone. On the south-eastern shores of the Caspian Sea and near the southwestern frontier of Central Asia series of pendants made of Didacna and Cerastoderma shells were found among the artefacts associated with the Epipalaeolithic assemblage of Ali Tappeh Cave (Manca et al., 2018). Various types of Mesolithic and Neolithic personal ornaments were recovered from burials (Kaylu; Tumek-Kichidjik), 
in multilayer cave sites (Dam-Dan-Cheshme-1 and -2; Jebel), in settlements (Janbas-4; Lyavlyakan-7, -99 and -402; Darbazakyr-2 and Karrykyzy-1), in workshop sites (Kuba-Sengir) and in surface scatters (Taji Kazgan-17; Bolshoi Tuzkan-12, -13, -19, -28-31 and -34; Pikent-3 and -5; Charyshly-1; Lyavlyakan-26, -34, -40, -101, -103, -105, -106 and -120; Khodjagumbaz-5; Ayakaghitma-90 and Beshbulak-1; Aidabol2, -6, -7, -9, -20, -25 and -26) (Tolstov, 1948; Vinogradov, 1955, 1981; Okladnikov, 1956; Gulyamov et al., 1966; Markov, 1966; Vinogradov and Mamedov, 1975; Bizhanov, 1982; Itina, 1984; Brunet, 2005). A large collection of rounded beads made of Didacna Eichwald mollusc shells ( $n>900$ ) occurs at the Kuba-Sengir archaeological site on the south-eastern Caspian Coast. The disc-shaped beads $(n=175$ ) recovered from the burials at the Kayliu Cave produced important information for the reconstruction of the burial rite of the Early Holocene population of this region (Shnaider et al., 2018). At the Mesolithic - Early Neolithic Lyavlyakan sites of the Kyzylkum Desert, many truncated-conic beads, flat disc-shaped beads, rounded pendants made of green and light blue turquoise and white calcite, as well as flat beads of mollusc shells were identified (Vinogradov and Mamedov, 1975).

While highland assemblages yield more animal bone in and Caspian sites exhibit a preference for shell, many sites located in transitional regions exhibit a diverse mix of all three material types. The Neolithic settlement of Jeitun, for example, is located at the junction between the Karakum desert and the foothill plain of the Kopet Dag mountains (8.3-8.0 ka cal BP) (Masson, 1971; Harris et al., 1993). At this site, elongated beads and cylinder-shaped beads decorated with linear incisions were made from animal bone, as were pendants with biconical perforation. However, Jeitun's ornaments also include disc-shaped beads made of marble, turquoise, and other types of stone, flat beads, and pendants made of Didacna and Cypraeidae mollusc shells. At Jeitun, unique zoomorphic and anthropomorphic figurines with drilled holes were also used as personal ornaments, possibly functioning as amulets. Other evidence of personal ornament production from osseous raw material is known from the Tumek-Kichidjik Late Neolithic burial ground at Trans-Unguz Karakum Desert (Vinogradov, 1981). This site includes 27 human burials, half of which yielded personal ornaments associated with red ochre. Some non-utilitarian items were found near the pelvis and femoral bones. These included small flat bone beads of the round and subrectangular shapes, Didacna mollusc shell round pendants with perforations, and flat beads made of soft stone. Ornaments of different types were also concentrated around the cranium: cylinder-shaped beads made of shells, pendants made of small predator fangs, and elongated beads made of bird tubular bones, some of which were decorated with linear incisions or deeper grooves. Large pendants with drilled holes at the ends made of boar fangs were found in two burials. These pendants represent remains of a peculiar necklace and were found between the neck and the abdomen. Although the symbolic traditions of high elevation occupants in the Pamir were poorly characterized before this research, our new results show the use of a diverse range of locally-available fauna for bone ornament production. Comparison with lowland areas of Central Asia reinforces a preference for locally-available materials in these regions. Mollusc shells and soft stone are the most popular in the Aral-Caspian depression, Amu-Darya-Syr-Darya interfluve and Ferghana valley. In contrast, sites of the Tian Shan region, Karakum desert and foothills of the Kopet Dag range exhibit a mix of faunal and stone raw materials.

\section{Conclusion}

The collection of personal bone ornaments from the Oshhona site provides new insight into the culture of the prehistoric populations of high altitudes in Central Asia. Our research shows that in the Middle Holocene period (prior to ca 7000 cal BP) in the Pamir mountains, a tradition of bone ornament production already existed in a developed form. Applying use-wear analysis and experimental data, we reconstructed the main techniques for the manufacturing of beads and pendants at the Oshhona site. According to the reconstruction, at least three operational sequences were employed by Oshhona inhabitants: manufacturing of barrel-shaped and cylinder-shaped elongated beads from tubular bones, creation of pendants with biconical perforation from the wall of tubular bones, and production of pendants with drilled holes from mammalian teeth. Production entailed the performance of several operations, beginning with fragmentation of the bone blanks by knapping or cutting, followed by shaping of the blanks by planing, drilling, and polishing. Although evidenced in our analysed assemblage, another operational sequence - the production of engraved bone items, - cannot be completely reconstructed at the moment, due to the fragmentation of available artefacts. Archaeozoological and biomolecular (ZooMS) analysis indicate that bone raw material belonging to a relatively wide range of wild animal taxa - deer, sheep, goat, cat, and rabbit/hare - were used to produce personal ornaments at Oshhona. This species diversity sits in contrast with the limited taxonomic diversity of the dietary assemblage at the site, which consisted primarily of sheep and goat remains. At the Oshhona site, the wide range of fauna remains used for the manufacture of the recovered ornaments indicates a non-exclusive use of specific raw materials. A cat bone, for example, was probably chosen deliberately for its cultural or spiritual significance, while other raw materials may have been selected based on practical considerations, such as availability or the size/shape of the desired skeletal elements. In total, the raw material and typological variability of the personal ornaments at Oshhona implies that specific preferences were used when choosing materials and for symbolic object manufacture. Ornaments and other non-utilitarian items made from rare raw material were often objects of prestige in ancient societies, and were gifted and exchanged during intergroup contacts (Bar-Yosef Mayer, 2005; Wright et al., 2008). Evidence of such practice is not apparent in the Oshhona archaeological record, where bone ornaments appear to have been used as personal items. We assume that the proliferation of symbolic activity across Central Asia in the Early and Middle Holocene might be linked to demographic increases or the appearance of new groups of people. This hypothesis is supported by an apparent increase in the number of archaeological sites and cultures in Central Asia following the end of the Pleistocene and the Last Glacial Maximum. Our research demonstrates that cultural adaptation to the diverse environments of Central Asia manifested in the selection of raw materials for personal ornaments, which appear consistently at Early Holocene sites from lowland territories to high mountain zones across the entire region. Comparison of the personal ornaments of Oshhona with collections from other areas dating to this period indicates that locally-available raw material was primarily selected for the production of non-utilitarian items, leading to regional differences in the use of bone, stone, and shell between high elevation, lowland, and Caspian-adjacent areas. Together, our results indicate the development of a robust tradition of animal-bone based ornament manufacture in highland Central Asia and the Pamir Mountains by ca. 7000 cal BP or before. Comparison of raw materials, manufacture technology, and typology of personal ornaments provide compelling evidence for cultural links between the Pamir mountains and the middle highlands of the Tian Shan. Although available anthropological and paleogenetic evidence is not yet numerous enough to assess the possibility of population movements linking these two regions, these results indicate a shared techno-cultural tradition or a common cultural adaptation, perhaps as a response to both available raw materials and emerging cultural preferences in montane environments during the first part of the Holocene. 


\section{Declaration of competing interest}

The authors declare that they have no known competing financial interests or personal relationships that could have appeared to influence the work reported in this paper.

\section{Acknowledgements}

We thank the organizers of the session and UISPP Congress 2018 for the invitation to participate in this special issue of Quaternary International. The analysis of personal ornaments and sampling for ZooMS analysis were supported by the Russian Foundation for Basic Research (RFBR) N॰18-09-40081 «Initial human colonization in the highlands of Western Central Asian (Pamir and Alay valley): cultural dynamics, chronology, palaeogeography» and the Max Planck Society. The radiocarbon dating and archaeozoological analysis were supported by the Russian Science foundation (RSF) No 19-78-10053 «The emergence of food-producing economies in the high mountains of interior Central Asia». We also thank the anonymous reviewers for their comments and suggestions.

\section{References}

Abuhelaleh, B., Al Nahar, M., Hohenstein, U.T., Berruti, G., Cancellieri, E. 2015. An Experimental Study of Bone Artifacts from the Neolithic Site of Tell Abu Suwwan (PPNB-PN), Jordan. Adumatu 32, 7-20.

Álvarez, M., Mansur, M.E., Pal, N. 2014. Experimental in bone technology: a methodological approach to functional: analysis on bone tools. In: Mansur, M.E., Lima, M.A., Maigrot, Y. (Eds.), Traceology Today: Methodological Issues in the Old World and the Americas, Vol. 6. Archaeopress, Oxford, pp. 19-26.

Averbouh, A. 2001. Methodological specifics of the Techno-economic Analysis of worked bone and antler: mental refitting and method of application. In: Choyke, A.M., Bartosiewicz, L. (Eds.), Crafting bone: Skeletal technologies through time and space. Archaeopress, Oxford, pp. 111-121.

Averbouh, A., Pétillon, J.-M. 2011. Identification of «debitage by fracturation» on reindeer antler: case study of the Badegoulian levels at the Cuzoul de Vers (Lot, France). In: Baron, J., Kufel-Diakowska, B. (Eds.), Written in Bones. Studies on technological and social contexts of past faunal skeletal remains. Uniwersytet Wrocławski, Institut Archeologii, Wrocław, pp. 41-51.

Bae, C.J., Douka, K., Petraglia, M.D. 2017. On the origin of modern humans: Asian perspectives. Science 358 (1269), eaai9067. doi: 10.1126/science.aai9067

Bar-Yosef Mayer, D.E., 2005. The exploitation of shells as beads in the Palaeolithic and Neolithic of the Levant. Paléorient 31 (1), 176-185. doi: 10.3406/paleo.2005.4796

Behrensmeyer, A.K. 1978. Taphonomic and Ecologic Information from Bone Weathering. Paleobiology 4 (2), 150-162. doi: $10.1017 /$ S0094837300005820

Bizhanov, B.E. 1982. Mesolithic and Neolithic sites of the North-West Ustyurt. In: Kamalov, S.K. (Ed.), Archaeology of the Aral Sea 1. FAN, Tashkent (in Russian).

Blumenschine, R.J., Curtis, W.M., Capaldo, S.D. 1996. Blind Tests of Inter-Analyst Correspondence and Accuracy in the Identification of Cut Marks, Percussion Marks, and Carnivore Tooth Marks on Bone Surfaces. Journal of Archaeological Science 23 (4), 493 507. doi: 10.1006/jasc.1996.0047

Bradfield, J., 2015. Use-wear analysis of bone tools: a brief overview of four methodological approaches. South African Archaeological Bulletin 70 (201), 3-14.

Brain, C.K. 1981. The Hunter or the Hunted. An Introduction to African Cave Taphonomy. The University of Chicago Press, Chicago and London.

Brantingham, P.J., Xing, G., Olsen, J.W., Haizhou, M., Rhode, D., Zhang, H., Madsen, D.B. 2007. A short chronology for the peopling of the Tibetan Plateau. Developments in Quaternary Sciences 9, 129-150. doi: 10.1016/S1571-0866(07)09010-0

Broglio, A., Cilli. C., Giacobini, G., Guerreschi, A., Malerba, G., Villa, G. 2004. Typological and Technological Study of Prehistoric Implements in Animal Hard Tissues. Collegium Antropologicum 28 (1), 55-61. 
Brunet, F. 2005. Pour une nouvelle étude de la culture néolithique de Kel'teminar, Ouzbékistan. Paléorient 31 (2), 87-105. doi: 10.3406/paleo.2002.4743 (in French).

Brunet, F. 2012. The Technique of Pressure Knapping in Central Asia: Innovation or Diffusion? In: Desrosiers, P. (Ed.), The Emergence of Pressure Blade Making: From Origin to Modern Experimentation. Springer, Québec, pp. 307-328. doi: 10.1007/978-1-46142003-3_12

Buc, N. 2011. Experimental series and use-wear in bone tools. Journal of Archaeological Science 38, 546-557. doi: 10.1016/j.jas.2010.10.009

Buc, N., Loponte, D. 2007. Bone Tool Types and Microwear Patterns: Some Examples from the Pampa Region, South America. In: Gates, St.-P.C., Walker R. (Eds.), Bones as tools: Current Methods and Interpretations in Worked Bone Studies. BAR International Series 1622. Archaeopress, Oxford, pp. 143-157.

Buckley, M., Collins, M., Thomas-Oates J., Wilson, J.C. 2009. Species identification by analysis of bone collagen using matrixassisted laser desorption/ionisation time-of-flight mass spectrometry. Rapid Communications in Mass Spectrometry 23 (23), 3843-3854. doi: $10.1002 / \mathrm{rcm} .4316$

Campana, D.V. 1979. A Natufian Shaft-Straightener from Mugharet El Wad, Israel: An Example of Wear-Pattern Analysis. Journal of Field Archaeology 6 (2), 237-242. doi: 10.2307/529368

Campana, D.V. 1989. Natufian and Protoneolithic Bone Tools. The Manufacture and Use of Bone Implements in the Zagros and the Levant. British Archaeological Reports, Oxford.

Chaix, R., Quintana-Murci, L., Hegay, T., Hammer, M.F, Mobasher, Z., Austerlitz, F., Heyer, E. 2007. From social to genetic structures in central Asia. Current Biology 17, 43-48. doi: 10.1016/j.cub.2006.10.058

d’Errico, F., Henshilwood, C., Lawson, G., Vanhaeren, M. Tillier, A.-M., Soressi, M., Bresson, F., Maureille, B., Nowell, A., Lakarra, J., Backwell, L., Julien, M., 2003. Archaeological Evidence for the Emergence of Language, Symbolism, and Music - An Alternative Multidisciplinary Perspective. Journal of World Prehistory 17 (1), 1-70. doi: 10.1023/A:102398020

d'Errico, F., Villa, P. 1997. Holes and Grooves: The Contribution of Microscopy and Taphonomy to the Problem of Art Origins. Journal of Human Evolution 33 (1), 1-31. doi: 10.1006/jhev.1997.0141

Dayet, L., Erasmus, R., Val, A., Feyfant, L., Porraz, G., 2017. Beads, pigments and early Holocene ornamental traditions at Bushman Rock Shelter, South Africa. Journal of Archaeological Science: Reports 13, 635-651. doi: 10.1016/j.jasrep.2017.05.015

Dennell, R., 2009. The Palaeolithic Settlement of Asia. Cambridge University Press, Cambridge. doi: 10.1017/CBO9780511818882

Derevianko, A.P., Rybin, E.P. 2003. The earliest representations of symbolic behavior by Paleolithic humans in the Altai Mountains. Archaeology, Ethnology \& Anthropology of Eurasia 15 (3), 27-50 (in Russian).

Derevianko, A.P., Shunkov, M.V. 2004. Formation of the Upper Paleolithic Traditions in the Altai. Archaeology, Ethnology \& Anthropology of Eurasia 19 (3), 12-40 (in Russian).

Derevianko, A.P., Tseveendorj, D., Olsen, D., Gladyshev, S.A., Rybin, E.P., Tserendagva, Ya., Chargynov, T.T., Bolorbat, Ts. 2006. Archaeological research of multilayer site Tolbor-4 in 2006. Problems of Archaeology, Ethnography, Anthropology of Siberia and Neighboring Territories 12 (1). IAET SB RAS Publ., Novosibirsk, 112-115 (in Russian).

Douka, K., Slon, V., Jacobs, Z., Ramsey, C.B., Shunkov, M.V., Derevianko, A.P., Mafessoni, F., Kozlikin, M.B., Li, B., Grün, R., Comeskey, D., Devièse, T., Brown, S., Viola, B., Kinsley, L., Buckley, M., Meyer, M., Roberts, R.G., Pääbo, S., Kelso, J., Higham, T., 2019. Age estimates for hominin fossils and the onset of the Upper Palaeolithic at Denisova Cave. Nature 565, 640-644. doi: 10.1038/s41586-0180870-z

Évora, M.A. 2015. Use-Wear Methodology on the Analysis of Osseous Industries. In: Marreiros, J.M., Gibaja Bao, J.F., Bicho Nuno, F. (Eds.), Use-wear and Residue Analysis in Archaeology. Springer International Publishing, Cham, pp. 159-170. doi: 10.1007/978-3319-08257-8_8

Fedorchenko, A.Yu. 2013. Performance test of Transverse burins from Northeast Asia. In: Chereshnev, I.A. (Ed.), Conference Dedicated to the Memory of Academian K.V. Simakov: Conference Proceedings. NESC FEB RAS, Magadan, pp. 280-281 (in Russian). 
Fedorchenko, A.Yu. 2016. Pieces with Burin Spalls from Cultural Layer VI of Ushki-I (Kamchatka Peninsula). Stratum plus 1, 223-241 (in Russian, with English abstract).

Fedorchenko, A.Yu., Seletskiy, M.V., Baumann, M., Kolobova, K.A. 2017. Experimental Study of the Middle Paleolithic Technique from the Chagyrskaya Cave Assemblages in 2017. Problems of Archaeology, Ethnography, Anthropology of Siberia and Neighboring Territories 23. IAET SB RAS Publ., Novosibirsk, pp. 214-217 (in Russian, with English abstract).

Fedorchenko, A.Yu., Shnaider, S.V., Krajcarz, M.T., Romanenko, M.E., Abdykanova, A.K., Kolobova, K.A., Alisher kyzy, S., Taylor, W., Krivoshapkin, A.I. 2018a. Personal Ornament Production Technology in the Early Holocene Complexes of Western Central Asia: Insights from Obishir-5. Archaeology, Ethnology \& Anthropology of Eurasia 46 (1), 3-15. doi: 10.17746/1563-0110.2018.46.1.003-015

Fedorchenko, A.Yu., Abdykanova, A., Shnaider, S.V., Tabaldyev, K.Sh., Krivoshapkin, A.I. 2018b. New Evidence of the Symbolic Behavior in the Epipalaeolithic of the Central Tien Shan. Eurasia in the Cenozoic. Stratigraphy, Paleoecology, Cultures 7, 242-251 (in Russian, with English abstract).

Fedorchenko, A.Yu., Belousova, N.E., Kulik, N.A., Shunkov, M.V. 2020. Early Upper Palaeolithic Serpentine ornaments from UstKarakol site, North-Western Altai. Archaeology, Ethnology \& Anthropology of Eurasia 48 (1), 3-15. doi: 10.17746/1563-0102.2020.48.1.003015

Gifford, D.P., Crader, D.C. 1977. A Computer Coding System for Archaeological Faunal Remains. American Antiquity 42 (2), 225-238. doi: 10.2307/278983

Goutas, N. 2015. From stone flaking to grinding: Three original Pavlovian antler tools from Moravia (Pavlov I, Czech Republic). Quaternary International 359-360 (2), 240-260. doi: 10.1016/j.quaint.2014.10.039

Gulyamov, Ya.G., Islamov, U., Askarov, A. 1966. Primitive culture and the emergence of irrigated agriculture in the lower reaches of Zarafshan. Fan Publ., Tashkent (in Russian).

Gurova, M., Bonsall, C. 2017. Experimental Replication of Stone, Bone and Shell Beads from Early Neolithic Sites in Southeast Europe. In: Bar-Yosef Mayer, D., Bonsal, C., Choyke, A.M. (Eds.), Not just for show: The Archaeology of Beads, Beadwork, \& Personal Ornaments. Oxbow Books, Oxford, pp. 159-167.

Gwinnett, A.J., Gorelick, L. 1998. A Brief History of Drills and Drilling. BEADS: Journal of the Society of Bead Researchers 10, $49-56$.

Harris, D.R., Masson, V.M., Berezkin, Y.E., Charles, M.P. 1993. Investigating early agriculture in Central Asia: new research at Jeitun, Turkmenistan. Antiquity 67 (255), 324-338. doi: 10.1017/S0003598X00045385

Heckel, C. 2016. Digital morphometric analysis of Upper Palaeolithic beads: Assessing artifact variability with user-friendly freeware. Journal of Archaeological Science: Reports 10, 893-902. doi: 10.1016/j.jasrep.2016.05.060

Islamov, U.I. 1975. Machai cave. Fan Publ., Tashkent (in Russian).

Islamov, U.I. 1980. Obishirian culture. Fan Publ., Tashkent (in Russian).

Islamov, U.I., Timofeev, V.I. 1986. Stone Age Culture of Central Fergana. Fan Publ., Tashkent (in Russian).

Itina, M.A. 1984. Rescue archaeological research in Horezm: results and prospects. Soviet ethnography 1, 42-59 (in Russian).

Khatsenovich, A.M., Rybin, E.P., Gunchinsuren, B., Bolorbat, Ts., Odsuren, D., Angaragdulguun, G., Margad-Erdene, G. 2017. Human and Struthio Asiaticus: One Page of Paleolithic Art in the Eastern Part of Central Asia. Bulletin of the Irkutsk state University. Geoarchaeology, Ethnology, and Anthropology series 21, 80-106 (in Russian, with English abstract).

Khlopachev, G.A., Girya, E.Yu. 2010. Secrets of Ancient Carvers in Eastern Europe and Siberia: Processing Techniques of Mammoth Tusk and Reindeer Antler in the Stone Age. Nauka Publ., Saint Petersburg (in Russian, with English abstract).

Kolobova, K.A., Shnaider, S.V., Krivoshapkin, A.I. 2016. Developmental Continuity Between the Upper Palaeolithic and Mesolithic Industries of Western Central Asia. Stratum Plus 1, 51-63 (in Russian, with English abstract). 
Kononenko, N. 2011. Experimental and archaeological studies of use-wear and residues on obsidian artifacts from Papua New Guinea. Technical Reports of the Australian Museum, Online 21, 1-244. doi: 10.3853/j.1835-4211.21.2011.1559

Korobkova, G.F. 1989. Mesolithic of Central Asia and Kazakhstan. In: Rybakov, B.A. (Ed.), Mesolithic of USSR. Nauka Publ., Moscow, pp. 149-174 (in Russian).

Korobkova, G.F., Sharovskaya, G.F. 2001. Stone Age bone tools (Diagnostics of Wear Traces on the Basis of Archaeological and Experimental Evidence). Arkheologicheskiye Vesti (Archaeological News) 8, 88-98 (in Russian, with English abstract).

Kuhn, S.L., Stiner, M.C. 2007. Body ornamentation as information technology: Towards an Understanding of the Significance of Early Beads. In: Mellars, P., Boyle, K., Bar-Yosef, O., Stringer, C. (Eds.), Body ornamentation as information technology: Towards an Understanding of the Significance of Early Beads. Rethinking the Human revolution. McDonald Institute for Archaeological Research, Cambridge, pp. 45-54.

Kuzmina, E.E. 2008. The Prehistory of the Silk Road. University of Pennsylvania Press, Philadelphia.

Lbova, L.V. 2000. Paleolithic of the northern zone of Western Transbaikalia. BNTs SO RAN Publ., Ulan-Ude (in Russian).

Legrand, A., Sidéra, I. 2007. Methods, Means, and Results When Studying European Bone Industry. In: Gates, St.-P.C., Walker R. (Eds.), Bones as tools: Current Methods and Interpretations in Worked Bone Studies. BAR International Series 1622. Archaeopress, Oxford, pp. 67-79.

LeMoine, G.M. 1994. Use Wear on Bone and Antler Tools from the Mackenzie Delta, Northwest Territories. American Antiquity 59 (02), 316-334. doi: 10.2307/281935

Maigrot, Y. 2003. Etude technologique et fonctionnelle de l'outillage en matières dures animales La station 4 de Chalain (Néolithique final, Jura, France). Thèse de Doctorat Université de Paris I, Paris (in French).

Manca, L., Mashkour, M., Shidrang, S., Averbouch, A., Biglari, F. 2018. Bone, shell tools and ornaments from the Epipalaeolithic site of Ali Tappeh, East of Alborz Range, Iran. Journal of Archaeological Science: Reports 21, 137-157. doi: 10.1016/j.jasrep.2018.06.023

Markov, G.E. 1966. Dam Dam Cheshme 2 Rockshelter in Eastern Caspian. Soviet Archaeology 2, 104-125 (in Russian).

Markov, Yu., Obraztsov, V.A. 1981. The dating of ancient sites of Turkmenia and Neighboring regions by radiocarbon analysis. Bulletin of Academia of Science of TSSR 6, 74-77 (in Russian).

Marreiros, J., Mazzucco, N., Gibaja J.G., Bicho, N. 2015. Macro and Micro Evidences from the Past: The State of the Art of Archeological Use-Wear Studies. In: Marreiros, J.M., Gibaja Bao, J.F., Bicho Nuno, F. (Eds.), Use-wear and Residue Analysis in Archaeology. Springer International Publishing, Cham, pp. 5-26. doi: 10.1007/978-3-319-08257-8_2

Martí, A.P., Wei, Y., Gao, X., Chen, F., d'Errico, F. 2017. The earliest evidence of coloured ornaments in China: The ochred ostrich eggshell beads from Shuidonggou Locality 2. Journal of Anthropological Archaeology 48, 102-113. doi: 10.1016/j.jaa.2017.07.002

Martisius, N.L., Sidéra, I., Grote, M.N., Steele, T.E., McPherron, S.P., Schulz-Kornas, E. 2018. Time wears on: Assessing how bone wears using 3D surface texture analysis. PLOS ONE 13 (11), e0206078. doi: 10.1371/journal.pone.0206078

Masson, V.M. 1971. The settlement of Jeitun, the problem of the formation of the economy of production. Nauka Publ., Leningrad (in Russian).

Meyer, M.C., Aldenderfer, M.S., Wang, Z., Hoffmann, D.L., Dahl, J.A., Degering, D., Haas, W.R., Schlütz, F. 2017. Permanent human occupation of the central Tibetan Plateau in the early Holocene. Science 355 (6320), 64-67. doi: 10.1126/science.aag0357

Motuzaite Matuzeviciute, G., Preece, R.C., Wang, S., Colominas, L., Ohnuma, K., Kume, S., Abdykanova, A., Jones, M.K. 2017. Ecology and subsistence at the Mesolithic and Bronze Age site of Aigyrzhal-2, Naryn Valley, Kyrgyzstan. Quaternary International 437 (B), 35-49. doi: 10.1016/j.quaint.2015.06.065

Narasimhan, V.M., Patterson, N., Moorjani, P., Rohland, N., Bernardos, R., Mallick, S., Lazaridis, I., Nakatsuka, N., Olalde, I., Lipson, M., Kim, A.M., Olivieri L.M., Coppa, A., Vidale, M., Mallory, J., Moiseyev, V., Kitov, E., Monge, J., Adamski, N., Alex, N., Broomandkhoshbacht, N., Candilio, F., Callan, K., Cheronet, O., Culleton, B.J., Ferry, M., Fernandes, D., Freilich, S., Gamarra, B., Gaudio, 
D., Hajdinjak, M., Harney, É., Harper, T.K., Keating, D., Lawson, A.M., Mah, M., Mandl, K., Michel, M., Novak, M., Oppenheimer, J., Rai, N., Sirak, K., Slon, V., Stewardson, K., Zalzala, F., Zhang, Z., Akhatov, G., Bagashev, A.B., Bagnera, A., Baitanayev, B., Bendezu-Sarmiento, J., Bissembaev, A.A., Bonora G.L., Chargynov, T.T., Chikisheva, T., Dashkovskiy, P.K., Derevianko, A., Dobeš, M., Douka, K., Dubova, N., Duisengali, M.N., Enshin, D., Epimakhov, A., Fribus, A.V., Fuller, D., Goryachev, A., Gromov, A., Grushin, S.P., Hanks, B., Judd, M., Kazizov, E., Khokhlov, A., Krygin, A.P., Kupriyanova E., Kuznetsov, P., Luiselli, D., Maksudov, F., Mamedov, A.M., Mamirov, T.B., Meiklejohn, C.M., Merrett, D.C., Micheli, R., Mochalov, O., Mustafokulov, S., Nayak, A., Pettener, D., Potts, R.D., Razhev, D., Rykun, M., Sarno, S., Savenkova, T.M., Sikhymbaeva, K., Slepchenko, S.M., Soltobaev, O.A. Stepanova, N., Svyatko, S., Tabaldiev, K., Teschler-Nicola, M., Tishkin, A.A., Tkachev, V.V., Vasilyev, S., Velemínský, P., Voyakin, D., Yermolayeva, A., Zahir, M., Zubkov, V.S., Zubova, A., Shinde, V.S., Lalueza-Fox, C., Meyer, M., Anthony, D., Boivin, N., Thangaraj, K., Kennett, D.J., Frachetti, M., Pinhasi, R., Reich, D. 2019. The formation of human populations in South and Central Asia. Science 365 (6457), eeat7487. doi: 10.1126/science.aat7487

Nokhrina, T.I., Taimagambetov, Zh.K. 1996. Personal Ornaments made of stone, bones and shells from the Karaungur cave (Southern Kazakhstan). Actual problems of Siberian Archaeology. Altai State University Publ., Barnaul, pp. $42-44$ (in Russian).

Okladnikov, A.P. 1951. The Earliest Archaeological sites of the Krasnovodsk Peninsula. In: Masson, M.E. (Ed.), Proceedings of the South Turkmen Archaeological Complex Expedition 2. Turkmen Branch of the USSR AS Publ., Ashgabat, pp. 73-104 (in Russian).

Okladnikov, A.P. 1956. The Jebel cave-site of the ancient culture of the Caspian tribes of Turkmenia. In: Masson, M.E. (Ed.), Proceedings of the South Turkmen Archaeological Complex Expedition 7. Turkmen Branch of the USSR AS Publ., Ashgabat, pp. 11-219 (in Russian).

Okladnikov, A.P. 1966. Paleolithic and Mesolithic of Central Asia. In: Masson, V.M., (Ed.), Central Asia in the era of stone and bronze. Nauka Publ., Moscow, pp. 11-75 (in Russian).

Olsen, S.L. 1984. Analytical approaches to the manufacture and use of bone artifacts in prehistory. Doctoral thesis, University of London, London.

Olsen, S.L., Shipman, P. 1988. Surface Modification on Bone: Trampling versus Butchery. Journal of Archaeological Science 15 (5), 535-553. doi: 10.1016/0305-4403(88)90081-7

Ozherelyev, D.V., Dzhasybyev, E.A., Mamirov, T.B. 2019. Investigations of the Rakhat Upper Palaeolithic Multilayered site in Southeast Kazakhstan. In: Gavrilov, K.N. (Ed.), The Cultural Geography of the Palaeolithic in the East-European Plain: from the Micoquian to the Epigravettian. Institute of Archaeology RAS Publ., Moscow, pp. 114-115 (in Russian).

Peltier, A., Plisson, H., 1986. Micro-traseologie functionnelle sur l'os: quelques resultats experimentaux. In: Patou, M. (Ed.), Outillage peu élaboré en os et bois de cervidé (II) 3. Artefacts, Treignes, pp. 69-80 (in French).

Pickering, T.R., Egeland, C.P. 2006. Experimental patterns of hammerstone percussion damage on bones: implications for inferences of carcass processing by humans. Journal of Archaeological Science 33 (4), 459-469. doi: 10.1016/j.jas.2005.09.001

Pinhasi R., Heyer E. 2015. Central Asia: Genetics and Archaeology. In: Bellwood, P. (Ed.), The Global Prehistory of Human Migration. Wiley Blackwell, Chichester, West Sussex, pp. 184-190.

Ranov, V.A. 1962. Excavations of primitive communal system sites in the Eastern Pamir at 1960. In: Archaeological works in Tajikistan in 1960-1962, iss. 8, pp. 6-25 (in Russian).

Ranov, V.A. 1988. Stone Age of Southern Tajikistan and the Pamir. Doctoral thesis abstract. Novosibirsk (in Russian).

Ranov, V.A., Karimova, G.R. 2005. Stone Age of the Afghan-Tajik Depression. Devashtish Press, Dushanbe (in Russian).

Ranov, V.A., Khudzhageldiev, T.U. 2005. The Stone Age. In: History of the Gorno-Badakhshan Autonomous Region, vol. 1: From ancient times to the latest period. Payvand, Dushanbe, pp. 51-107 (in Russian).

Rigaud, S., Vanhaeren, M., Queffelec, A., Le Bourdon, G., d'Errico, F. 2014. The way we wear makes the difference: residue analysis applied to Mesolithic personal ornaments from Hohlenstein-Stadel (Germany). Archaeological and Anthropological Sciences 6 (2), 133-144. doi: 10.1007/s12520-013-0169-9 
Rybin, E.P., 2014. Tools, beads, and migrations: Specific cultural traits in the Initial Upper Palaeolithic of Southern Siberia and Central Asia. Quaternary International 347, 39-52. doi: 10.1016/j.quaint.2014.04.031

Saidov, A.S., 2008. Mammals (Mammalia) of Pamir: conversation and management of resources. News of the Academy of Sciences of the Republic of Tajikistan. Department of biological and medical sciences, vol. 3 (164), 36-49 (in Russian).

Semenov, S.A. 1968. The development of technology in the Stone Age. Nauka Publ., Leningrad (in Russian).

Sharon, G. 2014. The Early Prehistory of Western and Central Asia. In: Renfrew, C., Bahn, P. (Eds.), The Cambridge World Prehistory. Cambridge University Press, Cambridge, pp. 1357-1378. doi: 10.1017/CHO9781139017831.086

Shnaider, S.V., Krajcarz, M.T., Viola, T.B., Abdykanova, A., Kolobova, K.A., Fedorchenko, A.Yu., Alisher-kyzy, S., Krivoshapkin, A.I. 2017. New investigations of Epipaleolithic in western Central Asia: Obishir-5. Antiquity 91 (360), e-3. doi: 10.15184/aqy.2017.208

Shnaider, S.V., Kurbanov, R.N., Alisher kyzy, S., Rigaud, S., Shangina, M.V., Krivoshapkin, A.I. 2018. The Results of Kaylu and Kuba-Sengir Sites Preliminary Study (Eastern Caspian, Turkmenistan). Problems of Archaeology, Ethnography, Anthropology of Siberia and Neighboring Territories 24. IAET SB RAS Publ., Novosibirsk, pp. 184-189. doi: 10.17746/2658-6193.2018.24.184-189 (in Russian, with English abstract).

Shnaider, S.V., Saifuloev, N.N. 2018. Archaeological sites of the western part of Central Asia (Alai Valley and the Eastern Pamirs) in the context of the initial human settlement of highlands. Bulletin of the Tajik National University 6, 9-13 (in Russian).

Shnaider, S.V., Kolobova, K.A., Filimonova, T.G., Taylor, W., Krivoshapkin, A.I. 2020. New insights into the Epipaleolithic of western Central Asia: The Tutkaulian complex. Quaternary International Volume 535, 139-154. doi: 10.1016/j.quaint.2018.10.001

Shunkov, M.V., Fedorchenko, A.Yu., Kozlikin, M.B. 2018. The Early Upper Palaeolithic Personal Ornaments from the Southern Chamber of Denisova Cave. Problems of Archaeology, Ethnography, Anthropology of Siberia and Neighboring Territories 24. IAET SB RAS Publ., Novosibirsk, pp. 198-202. doi: 10.17746/2658-6193.2018.24.198-202 (in Russian, with English abstract).

Slon, V., Mafessoni, F., Vernot, B., Filippo, C. de, Grote, S., Viola, B., Hajdinjak, M., Peyrégne, S., Nagel, S., Brown, S., Douka, K., Higham, T., Kozlikin, M.B., Shunkov, M.V., Derevianko, A.P., Kelso, J., Meyer, M., Prüfer, K., Pääbo, S. 2018. The genome of the offspring of a Neanderthal mother and a Denisovan father. Nature 561, 113-116. doi:10.1038/s41586-018-0455-x

Stemp, W.J., Watson, A.S., Evans, A.A. 2015. Surface analysis of stone and bone tools. Surface Topography: Metrology and Properties 4 (1), 013001. doi: 10.1088/2051-672X/4/1/013001

Tashak, V.I. 2002. Processing the ostrich eggs shell in the Upper Paleolithic of Transbaikalia. In: Alkin, S.V. (Ed.), History and Culture of East Asia. IAET SB RAS Publ., Novosibirsk, pp. 159-164 (in Russian).

Taylor, W., Shnaider, S., Abdykanova, A., Fages, A., Welker, F., Irmer, F., Seguin-Orlando, A., Khan, N., Douka, K., Kolobova K., Orlando L., Krivoshapkin, A.I., Bovin, N. 2018. Early pastoral economies along the Ancient Silk Road: Biomolecular evidence from the Alay Valley, Kyrgyzstan. PLoS ONE 13 (10), e0205646. doi: 10.1371/journal.pone.0205646

Taylor, W., Spengler, R., Shnaider, S., Krivoshapkin, A., Orlando, L., Abdykanova, A. 2019. Investigating Ancient Animal Economies and Exchange in Kyrgyzstan's Alay Valley. Antiquity 93 (367), e2. doi: 10.15184/aqy.2019.4

Tolstov, S.P. 1948. Ancient Horezm. The experience of historical and archaeological research. Moscow State University Publ., Moscow (in Russian).

Torres, H.R., Groman-Yaroslavski, I., Weinstein-Evron, M., Yeshurun, R. 2020. A micro-wear analysis of Natufian gazelle phalanx beads from el-Wad Terrace, Mount Carmel, Israel. Journal of Archaeological Science: Reports 31, 102304. doi: 10.1016/j.jasrep.2020.102304

Vanhaeren, M., d'Errico F., 2006. Aurignacian ethno-linguistic geography of Europe revealed by personal ornaments. Journal of Archaeological Science 33, 1105-1128. doi: 10.1016/j.jas.2005.11.017

Velliky, E.C., Porr, M., Conard, N.J. 2018. Ochre and pigment use at Hohle Fels cave: Results of the first systematic review of ochre and ochre-related artefacts from the Upper Palaeolithic in Germany. PLoS ONE 13 (12), e0209874. doi: 10.1371/journal.pone.0209874

Vinogradov, A.V. 1955. Neolithic Ornaments from Didacna mollusk shells (by materials from excavation sites in Northern Turkmenistan). Brief Reports of the Institute of the History of Material Culture 59, 135-139 (in Russian). 
Vinogradov, A.V. 1981. Ancient hunters and fishermen of the Central Asian interfluve. Nauka Publ., Moscow (in Russian).

Vinogradov, A.V., Mamedov, E.D. 1975. Primeval Lyavlyakan. Stages of the most ancient settlement and development of Inner Kyzylkum. Nauka Publ., Moscow (in Russian).

Wadley, L., Lombard, M., Williamson, B., 2004. The first residue analysis blind tests: results and lessons learnt. Journal of Archaeological Science 31, 1491-1501. doi: 10.1016/j.jas.2004.03.010

Wei, Y., d'Errico, F., Vanhaeren, M., Li, F., Gao, X. 2016. An Early Instance of Upper Palaeolithic Personal Ornamentation from China: The Freshwater Shell Bead from Shuidonggou 2. PLoS ONE 11 (5), e0155847. doi: 10.1371/journal.pone.0155847

Wei, Y., d'Errico, F., Vanhaeren, M., Peng, F., Chen, F., Gao, X. 2017. A technological and morphological study of Late Paleolithic ostrich eggshell beads from Shuidonggou, North China. Journal of Archaeological Science 85, 83-104. doi: 10.1016/j.jas.2017.07.003

Welker, F., Collins, M., Thomas, J., Wadsley, M., Brace, S., Cappellini, E., Turvey, S., Reguero, M., Gelfo, J., Kramarz, A., Burger, J., Thomas-Oates, J., Ashford, J., Ashton, P., Rowsell, K., Porter, D., Kessler, B., Fischer, R., Baessmann, C., Kaspar, S., Olsen, J., Kiley, P., Elliott, J., Kelstrup, C., Mullin, V., Hofreiter, M., Willerslev, E., Hublin, J., Orlando, L., Barnes, I., MacPhee, R. 2015. Ancient Proteins Resolve the Evolutionary History of Darwin's South American Ungulates. Nature 522, 81-84. doi: 10.1038/nature14249

Welker, F., Hajdinjak, M., Talamo, S., Jaouen, K., Dannemann, M., David, F., Julien, M., Meyer, M., Kelso, J., Barnes, I., Brace, S., Kamminga, P., Fischer, R., Kessler, B., Stewart, J., Paabo, S., Collins, M., Hublin, J. 2016. Palaeoproteomic Evidence Identifies Archaic Hominins Associated with the Châtelperronian at the Grotte Du Renne. Proceedings of the National Academy of Sciences of the United States of America 113 (40), 11162-11167. doi: 10.1073/pnas.1605834113

White, R. 2007. Systems of Personal Ornamentation in the Early Upper Palaeolithic: Methodological Challenges and New Observations. In: Mellars, P., Boyle, K., Bar-Yosef, O., Stringer, C. (Eds.), Rethinking the human revolution. McDonald Institute Monographs, Cambridge, pp. 287-302.

White, R., Normand, C. 2015. Early and Archaic Aurignacian Personal Ornaments from Isturitz Cave: Technological and Regional Perspectives. In: White R., Bourrillon, R., Bon, F. (Eds.), Aurignacian Genius: Art, Technology and Society of the First Modern Humans in Europe. P@lethnology, New York University, New York, pp. 138-164. doi: 10.4000/palethnologie.789

Wright, D., Nejman, L., d'Errico, F., Králík, M., Wood, R., Ivanov, M., Hladilová, Š., 2014. An Early Upper Palaeolithic decorated bone tubular rod from Pod Hradem Cave, Czech Republic. Antiquity 88 (339), 30-46. doi: 10.1017/S0003598X00050201

Wright, K.I., Critchley, P., Garrard, A., Baird, D., Bains, R., Groom, S. 2008. Stone Bead Technologies and Early Craft Specialization. Levant 40, 131-165. doi: 10.1179/175638008X348016

Zhang, X.L., Ha, B.B., Wang, S.J., Chen, Z.J., Ge, J.Y., Long, H., He, W., Da, W., Nian, X.M., Yi, M.J., Zhou, X.Y., Zhang, P.Q., Jin, Y.S., Bar-Yosef, O., Olsen, J.W., Gao, X. 2018. The earliest human occupation of the high-altitude Tibetan Plateau 40 thousand to 30 thousand years ago. Science 362 (6418), 1049-1051. doi: 10.1126/science.aat8824

Zhukov, V.A. The works of the Markansuy archaeological expedition in 1976. 1982. In: Archaeological research in Tajikistan 16, 31-40 (in Russian).

Zwyns, N., Gladyshev, S.A., Gunchinsuren, B., Bolorbat, T., Flas, D., Dogandžić, T., Tabarev, A.V., Gillam, C., Khatsenovich, A.M., McPherron, S., Odsuren, D., Paine, C.H., Purevjal, K., Stewart, J.R. 2014. The open-air site of Tolbor 16 (Northern Mongolia): Preliminary results and perspectives. Quaternary International 347, 53-65. doi: 10.1016/j.quaint.2014.05.043

Zwyns, N., Paine, C.H., Tsedendorj, B., Talamo, S., Fitzsimmons, K.E., Gantumur, A., Guunii, L., Davakhuu, O., Flas, D., Dogandžić, T., Doerschner, N., Welker, F., Gillam, J.C., Noyer, J.B., Bakhtiary, R.S., Allshouse, A.F., Smith, K.N., Khatsenovich, A.M., Rybin, E.P., Gunchinsuren, B., Hublin, J.-J. 2019. The Northern Route for Human dispersal in Central and Northeast Asia: New evidence from the site of Tolbor-16, Mongolia. Scientific Reports 9, 11759. doi: 10.1038/s41598-019-47972-1 